\title{
REPORT
}

\section{Field notes from the Conference of the European Society for Ecological Economics (ESEE), Budapest, Hungary, 20-23 June 2017}

\author{
Julien-François Gerber*
}

After a few years in South Asia, I was able to attend the Conference of the European Society for Ecological Economics (ESEE) in Budapest, Hungary, 20-23 June 2017, and to reconnect with some of my European colleagues in the field of ecological economics. What follows are best described as personal 'field notes' and cannot pretend to be 'objective' or comprehensive.

Among the regional societies for ecological economics, the ESEE is often seen as the one most closely sticking to the original heterodox roots of ecological economics. Clive Spash, for example, has convincingly argued that there are noticeable differences between the European and American schools of ecological economics, which are also reflected in their conference programmes. I was thus very curious to see whether the critical spirit of the ESEE was still alive.

Before the conference, a summer school was held for junior researchers. After the opening ceremony with ESEE President Irene Ring and the subsequent general reception on Tuesday evening, the next three days of the conference were intense. There were several morning keynotes, parallel panel sessions, poster presentations, and then afternoon keynotes and additional parallel panel sessions. It was, thus, a constant struggle to decide-between nine simultaneous panels-which had the most interesting and relevant presentations.

\footnotetext{
* International Institute of Social Studies (ISS), The Hague, the Netherlands; gerber@iss.nl Copyright (C) Gerber 2018. Released under Creative Commons Attribution-NonCommercial 4.0 International licence (CC BY-NC 4.0) by the author.

Published by Indian Society for Ecological Economics (INSEE), c/o Institute of Economic Growth, University Enclave, North Campus, Delhi 110007.

ISSN: 2581-6152 (print); 2581-6101 (web).

DOI: https://doi.org/10.37773/ees.v1i1.28
} 
Overall, the conference presented a few salient features. First, it was very interdisciplinary. This point was emphasized in the conference's introductory text: 'Academic and practitioner communities must enact meaningful participative and mutually empowering activities across disciplines and different knowledge systems.' Accordingly, individual presentations ranged from quantitative models of energy transitions to the role of emotions in ecological economics, and included several presentations on social movements, and even one on the neglected treatment of prisons in ecological economics. As a response to this thematic variety, no less than eight parallel panel sessions dealt with the problems of interdisciplinarity. Ecological economics as 'the science of sustainability' (R. Costanza) has to be at the forefront of interdisciplinary thinking.

Secondly, the conference sought to have an impact in promoting critical policies. The introductory text of the conference specified that 'Ecological economics can contribute to generating inclusive and reflective research in a number of ways: as transformative science; as advocacy for non-human beings and future generations; [and] as advocacy for environmental and social justice.' This emphasis on advocacy was palpable throughout the conference. The organizers explicitly defined ecological economics as being transformative not only at the social level but also, interestingly, at the individual level (its insights 'aim to encourage pathways to individual, collective and institutional change'). This welcoming attitude towards psychological and relational insights was observable in several presentations.

Third, the conference remained firmly heterodox in its outlook. The programme did not include any presentation framed along the standard standpoint of (neoclassical) environmental economics with its monodisciplinary focus on general equilibrium models with external costs. In Europe, authors working along this line share their work at the conferences of the European Association of Environmental and Resource Economists (EAERE), not at the ESEE. In this way, it would not be wrong to say that the ESEE maintains aspects of the non-orthodox spirit of the founding fathers like N. Georgescu-Roegen, K.W. Kapp, K. Boulding, C.S. Holling, and E.F. Schumacher.

The 'hot topics' at the ESEE this year were related to (1) fundamental reflections on the identity of 'socio-ecological economics' as an interdisciplinary field of inquiry (as mentioned above); (2) the quest for degrowth alternatives; (3) socio-metabolic analyses; (4) energy transitions; and (5) payments for ecosystem services.

This last topic-payment for ecosystem services-has always been an area of scientific and ethical contention within ESEE members and, of course, 
among ecological economists worldwide. Some ecological economists are sceptical about the possibility and soundness of commodifying ecosystem services, but others pragmatically embrace the idea. This opposition was exemplified this year in the diverging keynote lectures of Erik GómezBaggethun, who was generally critical of payments for ecosystem services, and Unai Pascual, who was in favour of some of them.

I was surprised, and pleased, to see the remarkable scientific and policy effort mobilized by European ecological economists towards clarifying and seeking ways of implementing a de-growth project. There were no less than twelve parallel panel sessions dealing with different aspects of de-growth or post-growth, such as the possible effects on employment, the role of technologies, public opinion about it, or the link with environmental justice movements. It really is the hot topic!

Besides the well-known critique of GDP as a useful indicator, there are today three main post-growth currents in ecological economics: de-growth, a-growth, and steady-state economics. De-growth promotes a 'civilizational change' towards a society with a smaller metabolism but, more importantly, towards a society with a metabolism that has a different structure and serves new functions. These new structure and functions are aimed at enhancing localized, democratic, and equitable economies, where material accumulation no longer holds a prime position in the population's value systems.

A-growth, for its part, is agnostic about growth: welfare and sustainable targets should be carefully defined, and whether these targets require growth is simply irrelevant. And steady-state economics promotes nongrowing societies based on a stable material and energy throughput and a stable population. European ecological economists work mostly on degrowth, often around Joan Martinez-Alier and, to a lesser extent, on agrowth while American ecological economists are more interested in steadystate economics, frequently around Herman Daly. But the three approaches can be seen as complementary.

This significant momentum of growth-critical approaches is not restricted to Western ecological economics; it is triggering debates also in Latin America and Asia, as exemplified in our forthcoming volume Post-growth thinking in India (co-edited by J.-F. Gerber and Rajeswari S. Raina, Orient Blackswan). At the end, I was relieved that the ESEE conferences seem to remain vibrant arenas of debates over some of the most pressing sustainability questions of our time. 